\title{
Testing of Nutmeg Shell as a Lightweight Concrete Material in Terms of Volume Weight and Compressive Strength Value
}

\author{
Budiman $^{\mathrm{a}, *}$

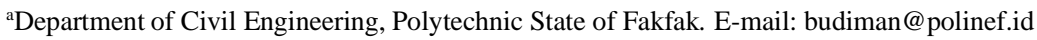

\begin{abstract}
Lightweight concrete can be defined as a type of concrete that includes an expanding agent in that it increases the volume of the mixture while giving additional qualities such as nailability and lessened the dead weight. The nutmeg shell has the characteristics of light and hard skin texture so that it has the potential to be used as a material for lightweight concrete. The purpose of this study is to determine the aggregate characteristic value and the compressive strength value of concrete using the DOE (design of experiment) method and referring to standards SNI. Variation of use nugmet shell toward the weight volume of concrete is $10 \%, 20 \%, 30 \%, 40 \%$, and $50 \%$. This research is sample-based laboratory research and analysis of aggregate characteristics and concrete compression test. The research result shows that the use of nutmeg skin as a coarse aggregate material in the concrete mixture affects the volume weight of the concrete. The weight of the concrete gets lighter along with the higher the percentage used. The average volume weight obtained was $1810.06 \mathrm{~kg} / \mathrm{m}^{3}$. Based on the weight of the concrete sample, it is classified as a light structure, includes concrete with low density and includes lightweight aggregate concrete. The compressive strength values for the characteristics of concrete at a composition of $10 \%, 20 \%$, and $30 \%$ were obtained at $28.42 \mathrm{~kg} / \mathrm{cm}^{2}, 31.65 \mathrm{~kg} / \mathrm{cm}^{2}$, and $32.68 \mathrm{~kg} / \mathrm{cm}^{2}$ which increased while the use of nutmeg shells at $40 \%$ and $50 \%$ compositions were obtained. values of $29.09 \mathrm{~kg} / \mathrm{cm}^{2}$ and $27.38 \mathrm{~kg} / \mathrm{cm}^{2}$ decreased at the age of 28 days. The increase in the value of the compressive strength of concrete (fck') occurred starting at the composition of $20 \%$ and $30 \%$ at $10.20 \%$ and $13.03 \%$ and begin to decrease at the composition of $50 \%$ by $3.65 \%$. Lightweight concrete from nutmeg shells has a weight of $1810.06 \mathrm{~kg} / \mathrm{m}^{3}$ and a maximum compressive strength value of $3.2 \mathrm{MPa}$ so that the concrete is in the category of lightweight structure.
\end{abstract}

Keywords: Compressive strength; lightweight concrete; nutmeg shell; volume weight

\section{Introduction}

Until now, Indonesia is one of the world's largest producers and exporters of mace and mace, with a market share of 75 percent. The main export destinations for Indonesian nutmeg are Vietnam, the United States, the Netherlands, Germany, and Italy. Indonesia's nutmeg production in 2011 reached 15,793 tonnes, which is produced from a production area of 118,345 hectares and involves 146,331 farmer family owners. Fakfak Regency is one of the main nutmeg producing areas in West Papua Province with production reaching 1,884 tons, 11 percent of Indonesia's total nutmeg production [1]. The production of this nutmeg is certainly comparable to the shell produced, the designation of the shell has not been used properly, it is only thrown away, burned, and piled up so that it becomes a pollutant for the environment.

The nutmeg shell has the characteristics of light and hard skin texture so that it has the potential to be used as a material for lightweight concrete. The use of nutmeg shell

${ }^{*}$ Corresponding author. Tel.: +62-812-7706-1052

Jalan TPA Imam Bonjol Atas Air Merah, Kelurahan Wagom Fakfak, Papua Barat, Indonesia 98611 as a light aggregate has never been used, so it is interesting to study. The use of certain proportions may affect the behavior of lightweight concrete structures as a whole.

Concrete is a composite material that consists of a cement paste within which various sizes of fine and coarse aggregates are embedded. It contains some amount of entrapped air and may contain purposely-entrained air by the use of air-entraining admixtures both natural and artificial added ingredients (bamigboy). In concrete construction, the concrete represents a very large proportion of the total load on the structure, and there are clearly considerable advantages in reducing its density. One of the ways to reduce the weight of a structure is the use of lightweight aggregate concrete (LWAC) [2].

Lightweight concrete can be defined as a type of concrete that includes an expanding agent in that it increases the volume of the mixture while giving additional qualities such as nailability and lessened the dead weight [3]. It is lighter than the conventional concrete with a dry density of $300 \mathrm{~kg} / \mathrm{m}$ up to $1840 \mathrm{~kg} / \mathrm{m} \quad 87$ to $23 \%$ lighter. It was first introduced by the Romans in the second century where 'The Pantheon' has been constructed using pumice,the most common type of aggregate used in that particular year [4]. From there on, the use of lightweight 
concrete has been widely spread across other countries such as USA, United Kingdom, and Sweden.

In recent years, more attention has been paid to the development of lightweight aggregate concrete [5]. The specific gravity of concrete can be lowered either by using porous, therefore lightweight aggregates instead of ordinary ones, or introducing air into the mortar, or removing the fine fractions of aggregate and compacting concrete only partially. In all cases, the main goal is to introduce voids into the aggregate and the mortar or between mortar and aggregate. A combination of these methods can also be made in order to reduce further the weight of concrete. The use of lightweight aggregates is by far the simplest and most commonly used method of making a lightweight concrete [6].

The use of light aggregate from polystyrene material and the addition of $20 \%$ sludge of fire, to the sand aggregate produced a compressive strength value of up to $71 \mathrm{~kg} / \mathrm{cm}^{2}$, although the porosity of concrete can be reduced due to the substitution of sludge in concrete [7]. Lightweight concrete from PTE-type plastic waste produces a compressive strength value of $17.49 \mathrm{M}$ of its use on unfavorable structures [8].

The main specialties of lightweight concrete are its low density and thermal conductivity. Its advantages are that there is a reduction of dead load, faster building rates in construction, and lower haulage and handling costs [4].

A porous lightweight aggregate of low specific gravity is used in this lightweight concrete instead of ordinary concrete. The lightweight aggregate can be natural aggregate such as pumice, scoria, and all of those of volcanic origin, and the artificial aggregate such as expanded blast-furnace slag, vermiculite, and clinker aggregate. The main characteristic of this lightweight aggregate is its high porosity which results in a low specific gravity [9].

This study utilizes natural aggregate from nutmeg shells as a substitute for coarse aggregate in lightweight concrete. The research was carried out in the laboratory material testing of Civil Engineering of Fakfak State Polytechnic. The research objective was to determine the effect of characteristics and values with a variety of nutmeg shell compositions of $10 \%, 20 \%, 30 \%, 40 \%$, and $40 \%$ on the weight of the concrete volume.

\section{Literature Review}

\subsection{Light concrete}

Lightweight concrete has a density of not more than $1900 \mathrm{~kg} / \mathrm{m}^{3}$ [10] and has a compressive strength value of 0.35-6.90 $\mathrm{MPa}$. while according to [11] lightweight concrete has a density between $1000-2000 \mathrm{~kg} / \mathrm{m}^{3}$. Types of lightweight concrete based on concrete weight and compressive strength [10] and Neville and Brooks [11] as shown in Tables 1 and 2.

Table 1. Types of lightweight concrete according to [10]

\begin{tabular}{|c|c|c|}
\hline $\begin{array}{c}\text { Weight concretes } \\
\left(\mathbf{k g} / \mathrm{m}^{3}\right)\end{array}$ & $\begin{array}{c}\text { Compressive } \\
\text { strength (MPa) }\end{array}$ & $\begin{array}{c}\text { Types lightweight } \\
\text { concretes }\end{array}$ \\
\hline $240-800$ & $0.35-6.9$ & Low-Density concretes \\
\hline $800-1440$ & $6.9-17.3$ & $\begin{array}{l}\text { Moderate Strength } \\
\text { lightweight concretes }\end{array}$ \\
\hline $1440-1900$ & $>17.3$ & $\begin{array}{l}\text { Structural lightweight } \\
\text { concretes }\end{array}$ \\
\hline
\end{tabular}

Table 2. Types of lightweight concrete according to [11]

\begin{tabular}{ccc}
\hline $\begin{array}{c}\text { Weight concretes } \\
\left(\mathbf{k g} / \mathbf{m}^{\mathbf{3}}\right)\end{array}$ & $\begin{array}{c}\text { Compressive } \\
\text { strength }(\mathbf{M P a})\end{array}$ & $\begin{array}{c}\text { Types lightweight } \\
\text { concretes }\end{array}$ \\
\hline $1400-1800$ & $>17$ & $\begin{array}{c}\text { Structural } \\
\text { lightweight } \\
\text { concretes }\end{array}$ \\
$500-800$ & $7-14$ & Masonry concretes \\
$<800$ & $0.7-7$ & Insulating concretes \\
\hline
\end{tabular}

Normal concrete is obtained by mixing Portland cement, water, and aggregate, while for lightweight concrete the constituent materials are very dependent on the type of lightweight concrete. According to [12] there are 3 types of lightweight concrete, namely lightweight aggregate concrete, foam concrete, and concrete without fine aggregate. The same thing was also conveyed by [13], several methods that can be used to reduce the weight of concrete include the following:

1. Making gas/air bubbles in the cement mix.

2. Using light aggregate, for example, fired clay, pumice stone, or artificial aggregate.

3. Making concrete without using fine aggregate grains (non-sand concrete).

Several parameters that affect the fine aggregate (sand) in determining the quality of the concrete are sludge content, moisture content, volume weight, absorption, specific gravity, fineness modulus, and organic content [14].

The level of sludge is the percentage of a size that passes filter No.200 according to ASTM and British Standards or 80 DIN (Germany) or standard filter hole size $=0.075 \mathrm{~mm}$. Laboratory testing is generally carried out by the washing method according to ASTM C-117 (2000 Sieve in Mineral Aggregate by Washing) Standard Test Method for Materials. Tolerance for testing the fine aggregate sludge content is $0.2 \%-6 \%$.

The water content in the aggregate is greatly influenced by the amount of water contained in the aggregate. The bigger the difference between the original aggregate weight and the aggregate weight after oven drying, the more water is contained by the aggregate and vice versa. The tolerance of testing moisture content in fine aggregate is $3 \%-5 \%$.

The volume weight is the ratio between the dry aggregate weight and its volume. The aim is to determine the weight of the fine aggregate. The test tolerance for fine aggregate is $1.4 \mathrm{~kg} / \mathrm{ltr}-1.9 \mathrm{~kg} / \mathrm{ltr}$.

The absorption is the percentage by weight of water that can be absorbed by the material to the weight of dry aggregate. Tolerance of testing fine aggregate $0.2 \%-2 \%$ and coarse aggregate $0.2 \%-4 \%$.

The specific gravity is the ratio between the weight of dry aggregate and the weight of distilled water whose content is the same as the aggregate content in a saturated state at a certain temperature. The test tolerance for fine aggregate is $1.6 \%-3.3 \%$.

The organic ingredients are materials contained in aggregates that can cause damage to concrete. The organic substances contained in fine aggregates generally come from destroyed plants, especially in the form of humus and organic sludge. Harmful organic substances include sugar, oil, and fat. Sugar can inhibit cement binding and the development of concrete strength, while oil and grease can 
reduce cement binding capacity. The test tolerance for fine aggregates is less than a value of 3 .

\subsection{Compressive strength}

Reference [15] provides an understanding of the compressive strength of concrete, which is the amount of load per unit area, which causes the concrete specimen to crumble when loaded with a certain compressive force, which is generated by a compression machine.

\section{Research Methodology}

\subsection{Research stages}

The stages of research consist of preparing tools and materials. The material consists of sand, cement, water, and nutmeg shells. Test the characteristics and characteristics of fine aggregate and count the combination of fine aggregate and nutmeg shell as coarse aggregate to get the suitable composition. Designing a concrete mix (mix design) with fck' $10 \mathrm{MPa}$. Making the composition of the concrete mixture with nutmeg shell variations of $10 \%, 20 \%, 30 \%, 40 \%$ and $50 \%$ of the weight of the concrete volume. Concrete maintenance for 3.7 and 28 days. Testing the compressive strength of concrete with a target of fck' $10 \mathrm{MPa}$.

\subsection{Characteristic testing}

Aggregate characteristic testing uses study literature as shown in Table 3 [15].

\subsection{Compressive strength testing}

Concrete compressive strength test results using compression machine test were analyzed by using compressive strength equation [15] :

$$
f c=\frac{P}{A}
$$

where

$$
\begin{aligned}
& f_{c}=\text { compressive strength }\left(\mathrm{kg} / \mathrm{cm}^{2}\right) \\
& P=\operatorname{load}(\mathrm{kg}) \\
& A=\text { the weighted cross-sectional area }\left(\mathrm{cm}^{2}\right)
\end{aligned}
$$

\section{Result and Discussion}

The results of testing the characteristics test of fine aggregate (sand) are shown in Table 4.

Table 3. Aggregate testing and method

\begin{tabular}{ccc}
\hline No & Types of testing & Method \\
\hline 1 & Filter Analysis & SNI 03-1968-1990 \\
2 & $\begin{array}{c}\text { Specific Weight and Fine } \\
\text { Aggregate Absorption } \\
\text { Specific Weight and }\end{array}$ & SNI 03-1970-1990 \\
& $\begin{array}{c}\text { Absorption of } \\
\text { Coarse Aggregates }\end{array}$ & SNI 03-1969-1990 \\
4 & Water Content & SNI 03-1971-1990 \\
5 & Volume Weight & SNI 03-4804-1998 \\
\hline
\end{tabular}

Table 4. The result of fine aggregate testing

\begin{tabular}{ccccc}
\hline No & $\begin{array}{c}\text { Aggregate } \\
\text { characteristics }\end{array}$ & Interval & $\begin{array}{c}\text { Testing } \\
\text { result }\end{array}$ & Description \\
\hline 1 & Mud levels & Maks. 5\% & $4.00 \%$ & Qualified \\
2 & Water content & $0.5-5 \%$ & $2.33 \%$ & Qualified \\
3 & Volume weight & $\begin{array}{c}1.4-1.9 \\
\text { kg/liter }\end{array}$ & 1.53 & Qualified \\
4 & Absorption & $0.2-2 \%$ & $1.01 \%$ & Qualified \\
5 & Specific weight & & & \\
& $\begin{array}{c}\text { Real S.W } \\
\text { Dry-based S.W } \\
\text { Dry-surfaced } \\
\text { S.W }\end{array}$ & $1.6-3.3$ & 1.737 & Qualified \\
& 1.6 & 1.768 & Qualified \\
6 & $\begin{array}{c}\text { Roughness } \\
\text { modulus }\end{array}$ & $1.5-3.8$ & 2.656 & Qualified \\
& & & & Qualified \\
\hline
\end{tabular}

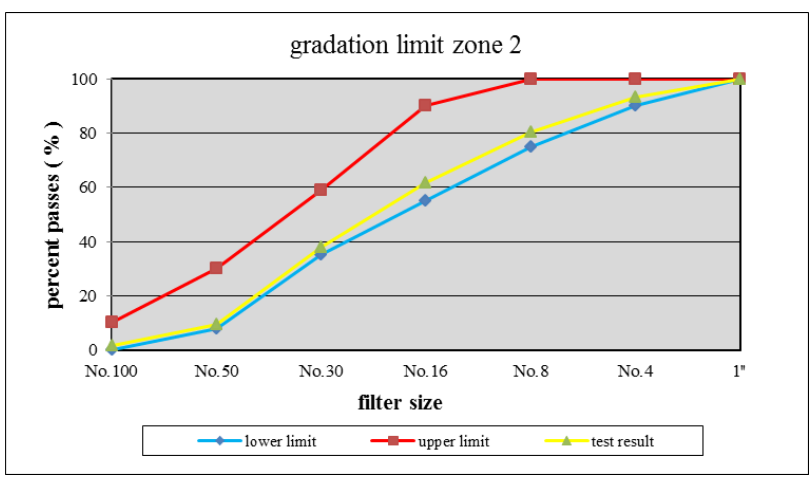

Figure 1. Graphic of fine aggregate gradation

The testing characteristics of fine aggregate, the value of sludge content is $4 \%$ and contains organic content which is suitable for use. According to [14] and [16], fine aggregate should not contain more than $5 \%$ sludge and not contain organic which can damage concrete. [17] A normal weight washed sand with a $(4.75 \mathrm{~mm})$ maximum size is used as fine aggregates its use is to fill the space between coarse aggregates and provide discomfort. The graphic of the test results for fine aggregate grains is shown in Fig. 1.

Based on Fig. 1, the modulus of fineness of 2.656 meets the requirements for zone 2. According to [14] a very good sand for concrete mixtures is sand with a zone 2 grading limit.

To know the strength of the concrete quality that will be produced using fine aggregate (sand) and coarse aggregate from nutmeg shells by calculating the aggregate with the cement water factor planning $(\mathrm{W} / \mathrm{C})=0.71$ as shown in Tables 5 - 9.

Table 5. The results of concrete mix design with nutmeg shell $10 \%$

\begin{tabular}{ccccc}
\hline $\begin{array}{c}\text { Concrete } \\
\text { material }\end{array}$ & $\begin{array}{c}\text { Weight } \\
\left(\mathbf{k g} / \mathbf{m}^{\mathbf{3}}\right)\end{array}$ & $\begin{array}{c}\text { Ratio to the } \\
\text { amount of } \\
\text { the cement } \\
\mathbf{( k g )}\end{array}$ & $\begin{array}{c}\text { Weight } \\
\text { for one } \\
\text { sample } \\
\mathbf{( k g )}\end{array}$ & $\begin{array}{c}\text { Weight } \\
\text { for one } \\
\text { sample } \\
(\mathbf{k g})\end{array}$ \\
\hline Water & 198.626 & 0.742 & 1.263 & 11.371 \\
Cement & 267.605 & 1.000 & 1.702 & 15.321 \\
Sand & 699.955 & 2.615 & 4.452 & 40.076 \\
CP 10\% & 21.990 & 0.082 & 0.139 & 1.259 \\
\hline Total & 1.188 & & 7.559 & 68.030 \\
\hline
\end{tabular}


Table 6. The results of concrete mix design with nutmeg shell $20 \%$

\begin{tabular}{ccccc}
\hline $\begin{array}{c}\text { Concrete } \\
\text { material }\end{array}$ & $\begin{array}{c}\text { Weight } \\
\left(\mathbf{k g} / \mathbf{m}^{\mathbf{3}}\right)\end{array}$ & $\begin{array}{c}\text { Ratio of the } \\
\text { amount of the } \\
\text { cement } \mathbf{( k g )}\end{array}$ & $\begin{array}{c}\text { Weight } \\
\text { for one } \\
\text { sample } \\
\mathbf{( k g )}\end{array}$ & $\begin{array}{c}\text { Weight } \\
\text { for one } \\
\text { sample } \\
(\mathbf{k g})\end{array}$ \\
\hline Water & 198.626 & 0.742 & 1.263 & 11.371 \\
Cement & 267.605 & 1.000 & 1.702 & 15.321 \\
Sand & 699.955 & 2.615 & 4.452 & 40.076 \\
CP 20\% & 23.32 & 0.087 & 0.148 & 1.335 \\
\hline Total & 1.189 & & 7.567 & 68.106 \\
\hline
\end{tabular}

Table 7. The results of concrete mix design with nutmeg shell $30 \%$

\begin{tabular}{ccccc}
\hline $\begin{array}{c}\text { Concrete } \\
\text { material }\end{array}$ & $\begin{array}{c}\text { Weight } \\
\left(\mathbf{k g} / \mathbf{m}^{\mathbf{3}}\right)\end{array}$ & $\begin{array}{c}\text { Ratio of the } \\
\text { amount of the } \\
\text { cement } \mathbf{( k g )}\end{array}$ & $\begin{array}{c}\text { Weight } \\
\text { for one } \\
\text { sample } \\
\mathbf{( k g )}\end{array}$ & $\begin{array}{c}\text { Weight } \\
\text { for one } \\
\text { sample } \\
\mathbf{( k g )}\end{array}$ \\
\hline Water & 198.626 & 0.742 & 1.263 & 11.371 \\
Cement & 267.605 & 1.000 & 1.702 & 15.321 \\
Sand & 699.955 & 2.615 & 4.452 & 40.076 \\
CP 30\% & 34.98 & 0.130 & 0.222 & 2.002 \\
\hline Total & 1.201 & & 7.641 & 68.773 \\
\hline
\end{tabular}

Table 8 . The results of concrete mix design with nutmeg shell $40 \%$

\begin{tabular}{ccccc}
\hline $\begin{array}{c}\text { Concrete } \\
\text { material }\end{array}$ & $\begin{array}{c}\text { Weight } \\
\left(\mathbf{k g} / \mathbf{m}^{\mathbf{3}}\right)\end{array}$ & $\begin{array}{c}\text { Ratio to the } \\
\text { amount of the } \\
\text { cement } \mathbf{( k g )}\end{array}$ & $\begin{array}{c}\text { Weight } \\
\text { for one } \\
\text { sample } \\
\mathbf{( k g )}\end{array}$ & $\begin{array}{c}\text { Weight } \\
\text { for one } \\
\text { sample } \\
(\mathbf{k g})\end{array}$ \\
\hline Water & 198.626 & 0.742 & 1.263 & 11.371 \\
Cement & 267.605 & 1.000 & 1.702 & 15.321 \\
Sand & 699.955 & 2.615 & 4.452 & 40.076 \\
CP 40\% & 46.64 & 0.174 & 0.296 & 2.670 \\
\hline Total & 1.212 & & 7.716 & 69.441 \\
\hline
\end{tabular}

Table 9. The results of concrete mix design with nutmeg shell $50 \%$

\begin{tabular}{ccccc}
\hline $\begin{array}{c}\text { Concrete } \\
\text { material }\end{array}$ & $\begin{array}{c}\text { Weight } \\
\left(\mathbf{k g} / \mathbf{m}^{\mathbf{3}}\right)\end{array}$ & $\begin{array}{c}\text { Ratio of the } \\
\text { amount of } \\
\text { the cement } \\
\mathbf{( k g )}\end{array}$ & $\begin{array}{c}\text { Weight } \\
\text { for one } \\
\text { sample } \\
\mathbf{( k g )}\end{array}$ & $\begin{array}{c}\text { Weight } \\
\text { for one } \\
\text { sample } \\
(\mathbf{k g})\end{array}$ \\
\hline Water & 198.626 & 0.742 & 1.263 & 11.371 \\
Cement & 267.605 & 1.000 & 1.702 & 15.321 \\
Sand & 699.955 & 2.615 & 4.452 & 40.076 \\
CP 40\% & 58.30 & 0.217 & 0.370 & 3.338 \\
\hline Total & 1.224 & & 7.790 & 70.109 \\
\hline
\end{tabular}

The calculation of the results of the design above, it is obtained that the difference in weight of light concrete with $10 \%$ nutmeg shells is obtained $1,188 \mathrm{~kg} / \mathrm{m}^{3}, 20 \%$ of $1,189 \mathrm{~kg} / \mathrm{m}^{3}, 30 \%$ of $1,201 \mathrm{~kg} / \mathrm{m}^{3}, 40 \%$ of $1,212 \mathrm{~kg} / \mathrm{m}^{3}$ and $50 \%$ of $1,224 \mathrm{~kg} / \mathrm{m}^{3}$. The weight value of the concrete shows that the use of nutmeg shells on the concrete affects the weight of the concrete itself and the compressive strength value of the concrete characteristics.

The results of testing the concrete mixture with nutmeg shells obtained an average correction water factor value of 0.30 . The recapitulation of the volume weight of fresh concrete from the test results was analyzed by the average weight value of fresh concrete obtained divided by the volume of cylindrical specimens as in Table 10 and Fig. 2.
Table 10. The weight volume of freshly concrete

\begin{tabular}{ccc}
\hline No & Sample & $\begin{array}{c}\text { Volume of Freshly } \\
\text { Concrete }\left(\mathbf{k g} / \mathbf{m}^{\mathbf{3}}\right)\end{array}$ \\
\hline 1 & Nutmeg shell concrete $10 \%$ & 1865,6 \\
2 & Nutmeg shell concrete $20 \%$ & 1837,3 \\
3 & Nutmeg shell concrete 30\% & 1792,4 \\
4 & Nutmeg shell concrete 40\% & 1780,2 \\
5 & Nutmeg shell concrete 50\% & 1774,8 \\
\hline
\end{tabular}

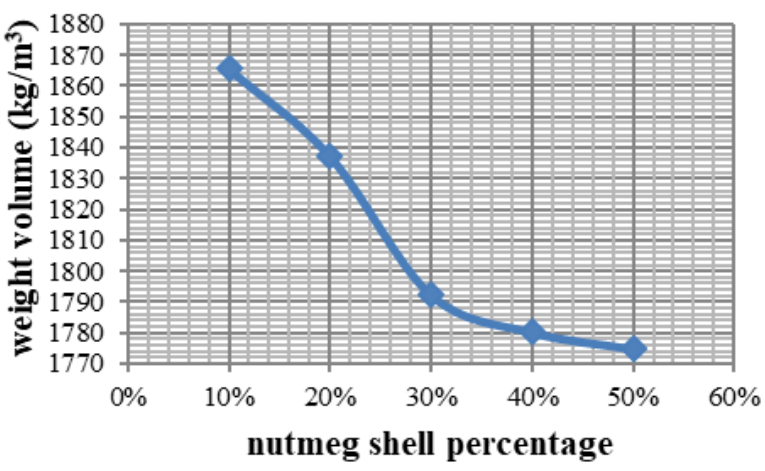

Figure 2. Weight volume

Based on Fig. 2 the weight of fresh concrete from $10 \%$ nutmeg is $1865.6\left(\mathrm{~kg} / \mathrm{m}^{3}\right)$ while for $50 \%$ it is obtained $1774.8\left(\mathrm{~kg} / \mathrm{m}^{3}\right)$, a decrease of $4.86 \%$. The greater the percentage value of nutmeg shells used in the lightweight concrete design mixture, the lighter the volume weight of the fresh concrete. This practice will enable the attainment of the specified fresh and hard concrete properties [18]. As also emphasized by Goldbeck and Gray [19] the use of appropriate mix proportions of materials for on-site concrete production will allow suitable mix proportions for certain strength characteristics to be achieved rather than the usual procedure of using unapproved mix ratios for design strength targeted.

The results of the analysis of the test value of the compressive strength of concrete using nutmeg shells at the age of 28 days, shows that light concrete with the use of nutmeg shells as coarse aggregate in the concrete mixture affects the compressive strength of the concrete characteristics (fck'). The compressive strength values for the characteristics of concrete at a composition of $10 \%$, $20 \%$, and $30 \%$ were obtained at $28.42 \mathrm{~kg} / \mathrm{cm}^{2}, 31.65$ $\mathrm{kg} / \mathrm{cm}^{2}$, and $32.68 \mathrm{~kg} / \mathrm{cm}^{2}$ which increased while the use of nutmeg shells at $40 \%$ and $50 \%$ compositions were obtained. The values of $29.09 \mathrm{~kg} / \mathrm{cm}^{2}$ and $27.38 \mathrm{~kg} / \mathrm{cm}^{2}$ decreased at the age of 28 days as in Table 10 and Fig. 3.

Table 11. The compressive strength characteristics of concrete

\begin{tabular}{ccc}
\hline No & Sample & Value fck' $\left(\mathbf{k g} / \mathbf{c m}^{2}\right)$ \\
\hline 1 & Nutmeg shell concrete 10\% & 28.42 \\
2 & Nutmeg shell concrete 20\% & 31.65 \\
3 & Nutmeg shell concrete 30\% & 32.68 \\
4 & Nutmeg shell concrete 40\% & 29.09 \\
5 & Nutmeg shell concrete 50\% & 27.38 \\
\hline
\end{tabular}




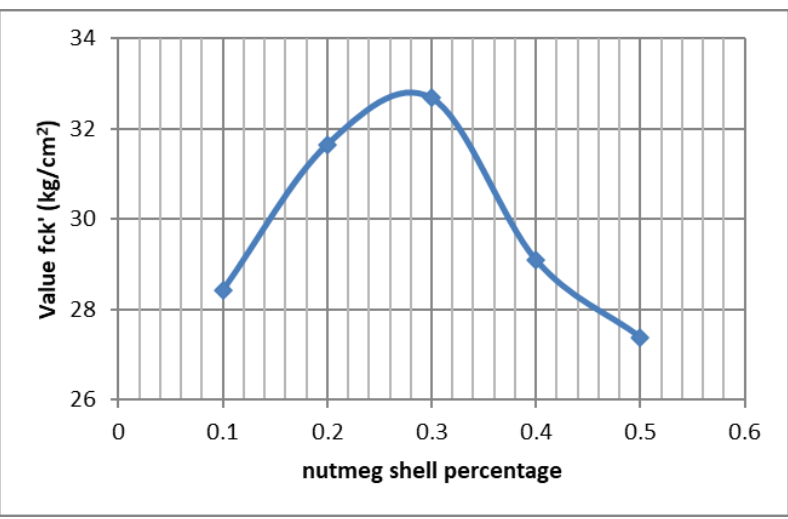

Figure 3. Value of fck'

As shown in Fig. 3 that the maximum concrete compressive strength (fck') value at the nutmeg shell composition is $30 \%$. The increase in the value of the compressive strength of concrete (fck') was $13.03 \%$ and began to decrease in the composition of $40 \%$ and $50 \%$ of $3.65 \%$. The decrease in the compressive strength value is influenced by the higher percentage of nutmeg shells that are used in the concrete mix, thereby reducing the volume of concrete that should be filled with cement paste. However, adding more nutmeg shells $40 \%$ and $50 \%$ of the volume of the concrete reduces the increase in compressive strength compared to $10 \%, 20 \%$, and $30 \%$ remains higher and this is attributed to the inclusion of cavities in the mixture as the excessive fiber content of it can lead to reduced bonding. and disintegration [20].

Lightweight concrete according to [21] is concrete with a concrete weight below $1860 \mathrm{~kg} / \mathrm{m}^{3}$ with types of lightweight concrete consisting of structural, lightweight and very light structural concrete. Lightweight concrete from nutmeg shells has an average weight of $1810 \mathrm{~kg} / \mathrm{m}^{3}$ and a maximum compressive strength value of $3,26 \mathrm{MPa}$ so that the concrete is in the lightweight structure category.

According to [10] and [11] lightweight concrete with low density has a concrete weight of $240 \mathrm{~kg} / \mathrm{m}^{3}-800$ $\mathrm{kg} / \mathrm{m}^{3}$ with a compressive strength value of $0.35-6.90$ Mpa. The range of compressive strength values, lightweight concrete from nutmeg shell is included in the lightweight concrete category with low density, so it can be concluded that nutmeg shell has the opportunity to be used as a building material for lightweight concrete.

Classification of lightweight concrete based on the weight of concrete If referring to [12], then most of the weight of light concrete in this study is classified as light structure as an insulator, [10] includes concrete with low density, the classification of [11] includes heat-resistant lightweight concrete and [13] includes lightweight aggregate concrete.

\section{Conclusion}

The use of nutmeg skin as a coarse aggregate material in the concrete mixture affects the volume weight of the concrete. The weight of the concrete gets lighter along with the higher the percentage used. The average volume weight obtained was $1810.06 \mathrm{~kg} / \mathrm{m}^{3}$. Based on the weight of the concrete sample, it is classified as a light structure, includes concrete with low density and includes lightweight aggregate concrete. The compressive strength values for the characteristics of concrete at a composition of $10 \%, 20 \%$, and $30 \%$ were obtained at $28.42 \mathrm{~kg} / \mathrm{cm}^{2}$, $31.65 \mathrm{~kg} / \mathrm{cm}^{2}$, and $32.68 \mathrm{~kg} / \mathrm{cm}^{2}$ which increased while the use of nutmeg shells at $40 \%$ and $50 \%$ compositions were obtained. values of $29.09 \mathrm{~kg} / \mathrm{cm}^{2}$ and $27.38 \mathrm{~kg} / \mathrm{cm}^{2}$ decreased at the age of 28 days. The increase in the value of the compressive strength of concrete ( $\left.\mathrm{fck}^{\prime}\right)$ occurred starting at the composition of $20 \%$ and $30 \%$ at $10.20 \%$ and $13.03 \%$ and begin to decrease at the composition of $50 \%$ by $3.65 \%$.

Further research is needed to determine the appropriate composition for both lightweight concrete and normal concrete. Further research is needed using a smaller percentage interval and It is recommended to use nutmeg shell as coarse aggregate in light concrete with a lowdensity scale and intended for light structures, besides saving costs, it can also reduce waste that has an impact on the environment.

\section{References}

[1] ILO-PCdP2 UNDP, 2018. Report Development Program Community Based Fakfak District Phase II: Implementing Institutionalization of Sustainable Livelihood Development for Papuans.

[2] Mouli, M.\& Khelafi, H. (2008). Performance characteristics of lightweight aggregate concrete containing natural pozzolan, Build. Environ. 43:31-36.

[3] Zakaria, M.L. (1978). Materials and Development, Language and Library Board.

[4] Samidi,M.R.(1997). First report research project on lightweight concrete, University Teknologi Malaysia, Skudai, Johor Bahru.

[5] Lo TY. Tang, WC. \& Cui, HZ. (2007). The effects of aggregate properties on lightweight concrete, Build. Environ. 42: 3025-3029.

[6] Gündüz, L. \& Uğur, I. (2005). The effects of different fine and coarse pumice aggregate/cement ratios on the structural concrete properties without using any admixtures, Cement Concrete Res. 35: 1859-1864.

[7] Fyzingsa., Dekarius Wiyan, Eka Selvi Elly Aggraeni, 2 009, Light Weight Making with the Addition of Lapindo Sludge and Artificial Aggregates in the Form of Polystiren, Thesis Engineering Study Program Sipil Inst itut Technology Sepuluh November, Surabaya.

[8] Pratikto, 2010, Lightweight Concrete Aggregated with PET (Polyetylene Terepthalate) Plastic Bottle Waste, National Seminar on Civil Engineering-2010, State Polytechnic of Jakarta, Jakarta.

[9] Lo, T.Y. \& Cui, H.Z. (2004). "Effect of Porous Lightweight Aggregate on Strength of Concrete", Materials and Letters, Vol.58, pp. 916-919.

[10]Dobrowolski, A. J., 1998, Concrete Construction Hand Book, The Mc. Graw Hill Companies, Inc., New York.

[11]Neville, A.M. and Brooks, J.J., 1987, Concrete Technology, John Willey \& Sons, New York.

[12]Raju, K.N., 1983, Design of Concrete Mixes, CBS Publishers \& Distributors, 485, Jain Bhawan, Bhola Nath Nagar Shandra, Delhi-110032 (India).

[13]Tjokrodimuljo Kardiyono, 1996. "Concrete Technology", Department of Civil Engineering, Faculty of Civil Engineering, Gajah Mada University.

[14]National Standard Agency. 2002. Procedure for C Light Concrete Mixing with Light Aggregate SNI 03-3449-2002. Jakarta: National Standard Agency.

[15]SK SNI 03-1974-1990. Concrete Compressive Strength. National Standardization Body. 1990.

[16]Li, Z. Advanced concrete technology. New Jersey: John Wiley \& Sons, 2011.

[17]Zinkaah, O. H. (2014). Influence of Steel Fibers on the Behavior of Light Weight Concrete Made from Crushed Clay Bricks. American Journal of Civil Engineering. Vol. 2, No. 4, 2014, pp. 109-116. doi : 10.11648/j.ajce.20140204.11

[18] Olusola, K. O., Babafemi, A. J., Umoh, A. A. and Olawuyi, B. J. Effect of batching methods on the fresh and hardened properties of concrete. International Journal of Research and Reviews in Applied Sciences, 13(3), 2012, pp 7-12. 
[19] Goldbeck, A. T and Gray, J. E. A method of proportioning concrete for strength, workability and durability. National Crushed Stone Association, Engineering Bulletin 11, 1968, pp 1-37.

[20]Dawood, ET. \& Ramli, M. (2009) "Study the effect of using palm fiber on the properties of high strength flowable mortar", CI Premier: 34th OWICs papers, Singapore. 2009; 93-101.
[21]Department of Public Works, 1994, Specification for Building Materials Part A (Non-Metal Building Materials), SNI 03-34491994, DPU of LPMB Foundation, Bandung. 